\title{
Charles Edward Price, J.P.
}

ThE death, on July 7, 1934, of Mr Price, formerly Member of Parliament for the Central Division of Edinburgh, removes from our Roll one who, although he had been a Fellow only since the year 1928, had been of substantial help to the Society at an earlier period, when its interests were critically affected.

$\mathrm{Mr}$ Price early in life joined with the late Mr Robert M'Vitie in forming what is now one of the largest firms in Britain, $M^{\prime} V$ Vitie \& Price. Retiring at a comparatively early age, he devoted himself to public work, both as a Member of Parliament for almost thirteen continuous years, and as identified with several commercial and philanthropic institutions in Edinburgh and other parts of the Kingdom. When in Parliament he played an important part in the negotiations with the Government of the day in securing for the Society the present premises, when it was dispossessed of its accommodation in the Royal Institution.

In recognition of his parliamentary services the Freedom of the City of Edinburgh was conferred on him in 1919.

J. W. 